\title{
RICHARD THOMAS LOWE, AN UNKNOWN BOTANICAL ILLUSTRATOR
}

\author{
Sandra Mesquita*, Cristina Castel-Branco** \\ $\&$ Miguel Menezes de Sequeira***
}

Abstract

Illustration is undoubtedly part of botanical history. In the early $19^{\text {th }}$ century, as botanical Latin yielded more accurate descriptions, the need for illustration in scientific publications decreased. Nevertheless, advances in printing processes boosted the production of illustrated botanical periodicals at accessible costs. Therefore, coloured depictions of plants never ceased to be part of botany at all levels. Richard Thomas Lowe (1802-1874) studied the flora of Madeira from 1826, when he first visited the island, to his death. He is well known as the author of Madeira's first comprehensive Flora, but his work as a botanical illustrator is poorly known. We analysed the graphic production related to his first major paper, published in 1831, along with written documents, which, altogether, support a more complete understanding of Rev. Lowe's botanical work in Madeira and his relevant activity as an illustrator. We believe that joint analysis of illustrations and correspondence show that Lowe himself made the drawings after which the plate of the orchid Goodyera macrophylla in this paper was prepared, whose authorship was, up to now, unknown.

KEYwORDs: botanical illustration, Goodyera macrophylla, Madeira, history of botany

\author{
RICHARD THOMAS LOWE: \\ UN ILUSTRADOR BOTÁNICO DESCONOCIDO
}

\section{RESUMEN}

La ilustración es indudablemente parte de la historia botánica. A comienzos del siglo XIX, cuando el latín botánico posibilitó descripciones más exactas, la necesidad de ilustraciones científicas decreció. Por otra parte, el desarrollo de las técnicas de impresión permitió la producción de revistas botánicas ilustradas periódicas a costes accesibles. Por ello, las láminas de plantas nunca han dejado de ser parte de la botánica a todos los niveles. Richard Thomas Lowe (1802-1874) estudió la flora de Madeira desde 1826, cuando visitó la isla por primera vez, hasta su muerte. Es bien conocido por haber sido el autor de la primera flora comprehensiva de Madeira, pero su labor como ilustrador botánico es poco conocida. En este trabajo analizamos la producción gráfica de su primer trabajo importante, publicado en 1831, junto con documentos escritos que juntos permiten conocer la extraordinaria labor del reverendo Lowe como botánico en Madeira, incluyendo su relevante actividad como ilustrador. Creemos que el análisis conjunto de sus ilustraciones y de su correspondencia muestra que fue el propio Lowe realizó los dibujos que dieron lugar a las láminas de Goodyera macrophylla de este trabajo, que hasta ahora se consideraban de autor desconocido.

PAlabras Clave: ilustración botánica, Goodyera macrophylla, Madeira, historia de la botánica. 


\section{INTRODUCTION}

Botanical illustration plays its part in the history of botany. Complementing herbarium specimens, it was the only way, until the beginning of the $19^{\text {th }}$ century, to register colour, physiognomy and other details less resistant to decay.

By the early $19^{\text {th }}$ century, botanical Latin was largely developed and thoroughly precise, and thus the importance of illustration as a means to convey plant features in scientific publications decreased (Stern 1966). Nevertheless, the production of botanical illustration did not diminish, since some botanists still found it useful to produce detailed depictions of plants along with descriptions. This relation is discussed, for instance, by Felix Avelar Brotero (1744-1828) who, despite advocating the adequacy of words for accurately describing minute details in plants (1788), later recognized the advantages of combining detailed descriptions with good quality illustrations. His "Phytographia Lusitaniae" $(1816 ; 1827)$ encompasses 181 splendid engravings (Castel-Branco 2004). Moreover, the, popularity of botany with the general public grew in that period. The quality of illustrations increased enormously, since living specimens were now commonly available in botanical gardens, and artists no longer had to rely on flat, dried herbarium specimens (Chansignaud 2016). Illustrated books became luxury items for wealthy collectors, and the production of expensive botany volumes, often hand-coloured, thrived (Chansignaud 2016). At the same time, the middle classes developed an interest in gardens and plants, and became avid consumers of less expensive publications with coloured botanical illustrations (Secord 2002). Advances in the production of paper and printing processes reduced publication costs and periodicals on botany and gardening multiplied (Chansignaud 2016; Burns 2017).

The utility of coloured representations in teaching natural history was a topic of public discussion in the 1830s (Secord 2002), but its value was acknowledged long before by botanists. Two noteworthy examples are those of William Jackson Hooker (1785-1865) and John Stevens Henslow (1796-1861). William Hooker, whilst professor of Botany in Glasgow University from 1820 to 1841, supplied his students with copies of his book "Botanical illustrations: being a series of figures designed to illustrate the terms employed in a course of lectures on botany, with descriptions", published in 1822 (Secord 2002). John Henslow was a professor at Cambridge, of mineralogy from 1822 and of botany from 1827. His lectures were extremely popular, in part due to the use of coloured illustrations and large diagrams, as stated by some of his most prominent pupils (Darwin 1877, July 6; Jenyns 1862).

* CEABN - InBio, Instituto Superior de Agronomia, Universidade de Lisboa, Lisboa, Portugal. Corresponding author: mesquita.s@gmail.com.

** Madeira Botanical Group (GBM), Faculdade de Ciências da Vida, Universidade da Madeira, Funchal, Portugal.

*** CIBIO, Centro de Investigação em Biodiversidade e Recursos Genéticos, InBIO Laboratório Associado, Ponta Delgada, Portugal. 
Drawing was an important tool in botanical practice: for students, it was a tool for developing observational skills; in common practice, a way to record traits which do not fit in herbarium sheets, like cumbersome organs, plant habit and habitat; in expeditions to distant places, it was used to record particularly delicate or perishable features of specimens, like flower colour in orchids (Bleichmar 2006; Francisco-Ortega et al. 2015); and as part of the process of acquiring and producing knowledge, since the act of drawing requires the careful observation of the subject in order to select the fundamental aspects of the plants depicted, understanding in this procedure what are the distinguishing characters of the plant and how to synthesise such information (Secord 2002). We believe that Lowe's illustration practice is an example of the latter and that it was part of his methodology to approach the flora of Madeira in his early years.

Richard Thomas Lowe (1802-1874) was born in Derbyshire, England, and studied at Cambridge University, where he attended Henslow's lectures. Henslow used to take his students on botanical field trips, and Lowe probably developed his interest in botany at that time, learning from Henslow the importance of direct observation and the convenience of drawing for recording new findings (Jenyns 1862).

Lowe first visited Madeira in 1826 and spent a year on the island as Travelling Bachelor of the University of Cambridge (Peile 1913), staying afterwards as temporary chaplain and finally as chaplain of the English Church, from 1833 to 1852 , regularly returning afterwards (Newell 1931). Lowe became interested in the local flora and fauna. Throughout his life, he assembled substantial natural history collections, including an impressive herbarium, and published more than 60 papers and books on the flora, fishes and terrestrial molluscs of the archipelagos of Madeira, Canaries and Cape Verde. Some of his earlier works were illustrated, and the authors responsible for the original drawings were usually identified, except for a magnificent lithography of a native Madeiran orchid (Goodyera macrophylla).

In this paper, we establish Lowe's authorship of the orchid's plate by analysing his correspondence, surviving sketches and drawings that may positively be attributed to him. Therefore, we aim to disclose a less known facet of this botanist, that of botanical illustrator. We also emphasise the importance of botanical illustration as a tool in the development of Lowe's pioneer work in studying in loco the flora of Madeira. The results presented here are part of a broader research on Lowe's work, in particular on the different forms of graphic production associated to his activity in natural history.

\section{MATERIALS AND METHODS}

An analysis of all 61 publications of Richard Thomas Lowe on natural history shows that 18 of these are illustrated: twelve on flora, five on fauna and one covering both subjects. These publications contain a total of 16 illustrations of plants, published from 1831 to 1835 , mostly after original drawings and watercolours by his friends Rev. Miles Joseph Berkeley (1803-1889), Miss Mary Young (1790-1843), 
and the Hon. Miss Caroline Norton (1798-1875). Lowe himself signs three of the illustrations. However, one of the six illustrations in the paper "Primitiae Faunae et Florae Madera et Portus Sancti", published in 1831 in Transactions of the Cambridge Philosophical Society (volume 4, pages 1 to 70), a splendid folded plate, is not signed and its author is in no other way mentioned.

Illustrated publications, original drawings and Lowe's correspondence were analysed in an attempt to shed some light on the origin of the unsigned plate published in 1831. We made use of the collection of drawings and watercolours marked "Ex Bibl. R.T. Lowe" held by the Archives at the Royal Botanical Gardens, Kew (RBGK), and probably bought in the auction of Lowe's library at Sotheby's in 1875 , although no original material is listed in the printed catalogue of the auction ${ }^{1}$ (Sotheby, Wilkinson \& Hodge 1875). Some of these drawings were signed "R.T.L." in Lowe's handwriting, others were signed by others, usually people close to Lowe, but most are unsigned.

William Jackson Hooker was a friend of Lowe's and his chief correspondent regarding botanical matters. Hooker was Professor of Botany in Glasgow University and, from 1841, Director of the RBGK (Brittain 2006). At least from 1827 onwards, Lowe and Hooker corresponded regularly, the letters received by Hooker kept in the Director's Correspondence collection at the RBGK and totalling 82.

Letters addressed to other correspondents and including useful information for this task were also retrieved: 3 letters addressed to Robert Brown (1773-1858) and kept at the British Library; 4 letters sent to Charles Darwin (1809-1882), available through the Darwin Correspondence Project ${ }^{2}$; 8 letters to Henslow from his early years in Madeira, kept at the Cambridge University Archives; 9 letters to Leonard Jenyns (1800-1893), kept at the Bath Royal Literary and Scientific Institution; and 7 letters sent to Philip Barker Webb (1793-1854), available through the Proyecto Humboldt ${ }^{3}$. Robert Brown was Keeper of the Botanical Collection at the British Museum, occupying a central position in European Botany in the mid-nineteenth century (Mabberley 2009). Darwin needs no introduction, and both Leonard Jenyns (later Blomefield) and Philip Barker Webb were friends of Lowe's. The first was an accomplished naturalist, one of the founding members of the Zoological Society of London, and the latter was a wealthy traveller and botanist who studied the natural history of the Canary Islands.

1 There is no definite evidence on this. It is a supposition, proposed by the Illustrations Team at Kew Archives, with which we agree.

2 Available at http://www.darwinproject.ac.uk.

3 Available at http://humboldt.fundacionorotava.es. 


\section{RESULTS}

Lowe's first major publication about Madeira-"Primitiae Faunae et Florae Madera et Portus Sancti" (Lowe 1831)-is a long paper, read at a Cambridge Philosophical Society's meeting on the $15^{\text {th }}$ November 1830, in which he describes 67 species of plants, most of them proposed as new to science, and 71 species of molluscs. Lowe talks about his plans concerning this publication in two letters written on April $23^{\text {rd }}$, to his friends Leonard Jenyns and Robert Brown:

I am looking out every day for a Vessel to convey my mother and myself to England; and I shall try to get down to Cambridge as soon as possible after landing. [...] My intention now is, to throw off this summer a sort of Prodromus Prodromi: in the shape of a pamphlet, merely containing the specs. chars. of my new land Mollusca and plants [...] I shall be anxious to hear how you like my plan; of w[hi] ch however I can now (when we meet) give you a better analysis than it contains. (Lowe 1830a, April 23).

I am also thinking of getting out my new species of plants in a brief form during the course of the present Summer, as a precursor to a more general work. [...] I hope to obtain yr. opinion on these $\&$ some other points, I have particularly an Orchideous plant $\&$ a Fern w[hi]ch I reserve, to have the pleasure of communicating with you personally about them. The former I hope to prove a new Genus. (Lowe 1830b, April 23).

His enthusiasm for the new orchid species had already been discussed with a closer friend, Philip Barker Webb, an English botanist then living in the Canary Islands. In a letter sent in November 1829, Lowe tells Webb about the time spent in the North part of Madeira Island during September and October that year and of the results of his explorations, mentioning the orchid for the first time, as well as the drawings he made of this plant:

I added about 30 Phaenog. plants to the Flora while I was at Sta. Anna. One a lovely Orchideous plant I think a new genus allied to Neottia (if not Ponthieva R.Br.). I have only been able to get one specimen in flower. The spike I have preserved in spirits \& made accurate drawings of the whole plant. (Lowe 1829, November 12).

Back in England in the summer of 1830, Lowe prepared the publication and the illustrations and engravings required, as he describes to Professor Henslow and, a few days later, to his friend W.J. Hooker:

Sowerby ${ }^{4}$ is hard at work (I hope) with my shells, making the requisite figures, for $\mathrm{w}$ [hi]ch he is to have $3 \mathrm{~s}$. a piece. About 50 figs. I believe will be requisite, - that is to be done by him, for I shall furnish some myself. [...] I have chosen a man

\footnotetext{
${ }^{4}$ George Brettingham Sowerby (1812-1884), naturalist, illustrator and conchologist.
} 
named Zeiter ${ }^{5}$ to engrave them. To my judgment he is the best [...] in London. [...] Engelman ${ }^{6}$ has got my new Goodyera (macrophylla) to littograph. A plain plate will answer every purpose $\&$ is to cost (engraving) $2 £$ I have contrived that the plant shall be packed into a single folded (not double) plate. (Lowe 1830, August 22).

I left with Mr. Hunneman ${ }^{7}$ for you a box of plants of Goodyera which proves new and which I have called Goodyera macrophylla. I only found it last autumn, and after carrying the plant twice across the island, had at last the satisfaction to see it flower. I brought drawings of it with me which were intended for should be underlined, but they have beholded so handsomely to me at Cambridge about the plates for my intended paper in the Philosophical Society Transactions that I am now having them lithographed by Engelmann for myself to accompany the paper. I hope your plants will do well, for it is excessively rare. (Lowe 1830, August 31).

However, due to problems with the illustrations of land shells, the publication was delayed, as Lowe explains to Hooker:

I am very busy now getting my shells engraved $\& c-\&$ my paper is with the printer though owing to an unfortunate mistake of mine in leaving some shells behind in $\mathrm{Mad}^{\mathrm{a}} \mathrm{w}$ [hi]ch must be fig[ure]d I fear it cannot be regularly publ[ishe]d before Spring. (Lowe 1830, October 26).

Finally, in 1831-in June, according to a handwritten note of undetermined authorship in the copy held by the Library and Archives at the Natural History Museum, London-the paper was published in the part I of volume 4 of the "Transactions of the Cambridge Philosophical Society", with 6 plates $^{8}$, all engraved by Engelmann, Graf, Coindet \& Co.: Goodyera macrophylla, unsigned (presented in figure 1), a folded plate depicting the whole plant in natural size and eleven details of the flower; Tolpis crinita and Ononis dentata, signed by Miles Joseph Berkeley; Sedum fusiforme, signed "R.T.L."; and two plates with illustrations of 26 and 40 shells, both signed by George Brettingham Sowerby Jr.

The original watercoloured drawing of Sedum fusiforme, signed by Lowe himself, together with a proof of the plate, is held at Kew Archives, marked "Ex Bibl. R.T. Lowe", as is the original watercolour of Tolpis crinita and a proof of the published illustration.

The collection of drawings held at Kew includes two watercolours of Goodyera macrophylla, both signed by Richard Thomas Lowe (presented in figures 2 and 3). The first drawing, of the whole plant, although with the inflorescence cut

${ }^{5}$ John Christian Zeitter (1797-1862).

${ }^{6}$ Engelmann, Graf, Coindet \& Co., the London branch of Franco-German Godefroy Engelmann's lithographic printing business, opened in 1826 and closed in 1830 .

7 John Hunneman (fl. 1820-1839), a London bookseller and agent specialized in botany.

8 This article was fully reprinted in 1833; and again in 1851, without the plant plates and corresponding explanatory notes (Stafleu \& Cowan 1831). 


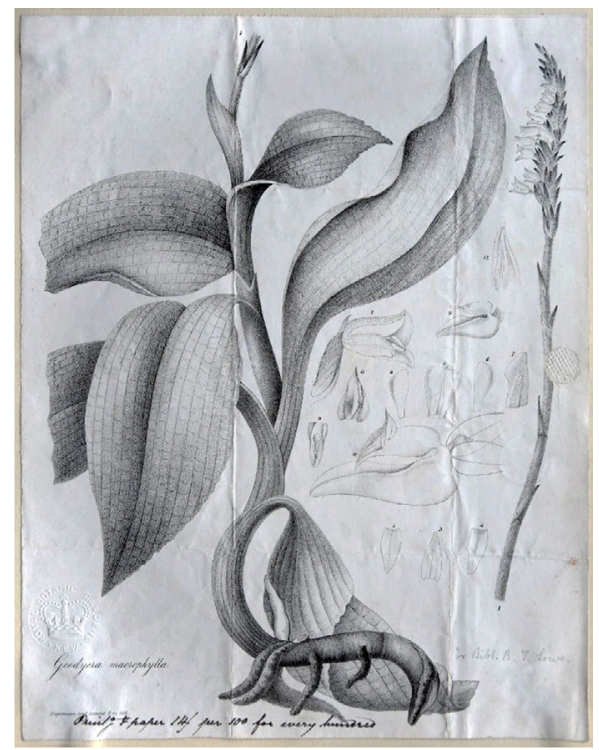

Figure 1. Goodyera macrophylla Lowe. Tab. I. Lowe, RT. 1831. Primitiæ faunæ et floræ Maderæ et Portus Sancti sive, Species quædam novæ vel hactenus minus rite cognitæ animalium et plantarum in his insulis degentium breviter descriptæ. Transactions of the Cambridge Philosophical Society 4: 1-70; pl. 1-6. () Copyright The Board of Trustees of the Royal Botanic Gardens, Kew.

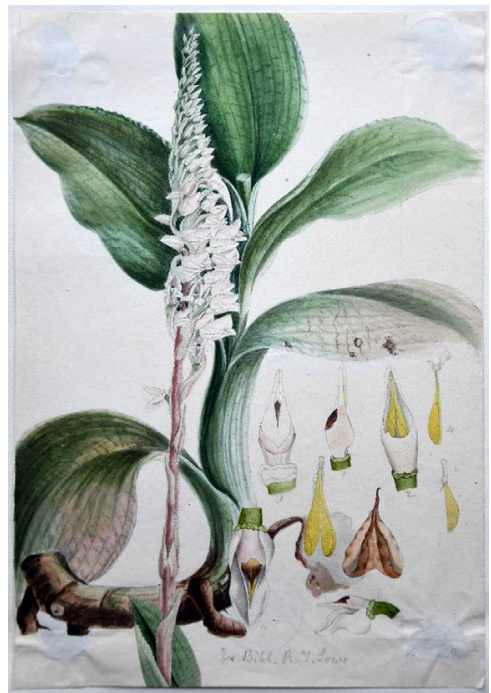

Figure 2. Goodyera macrophylla Lowe. Watercoloured drawing by Richard Thomas Lowe. (C) Copyright The Board of Trustees of the Royal Botanic Gardens, Kew.

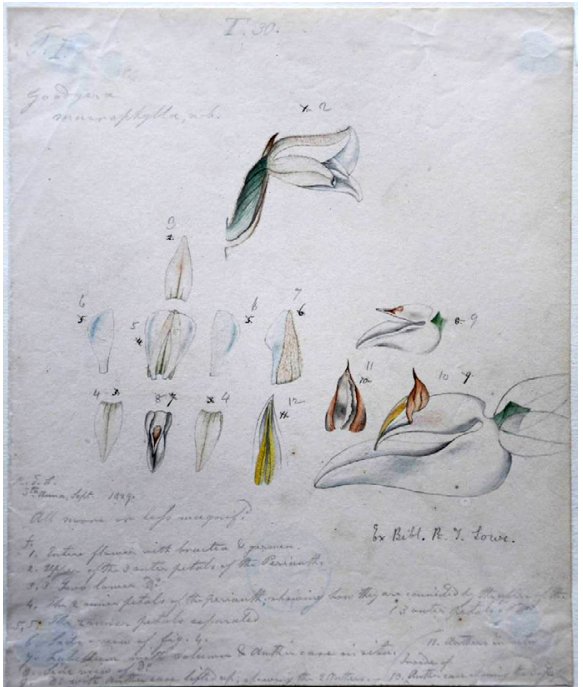

Figure 3. Goodyera macrophylla Lowe, flower details. Watercoloured drawing by Richard Thomas Lowe. (C) Copyright The Board of Trustees of the Royal Botanic Gardens, Kew. 
and presented separately, includes nine separate depictions of details of the flower, five of them numbered one to four; it is signed in the bottom right corner "R.T.L. delt." in Lowe's handwriting. The second drawing depicts the whole flower and 12 details, numbered one to eleven in ink and then corrected to two to twelve in pencil; it is signed and dated "R.T.L. Sta. Anna, Sept. 1829", again in Lowe's handwriting, and includes, also in pencil, the plant name and explanatory notes for the details.

\section{DISCUSSION}

Comparing the Goodyera macrophylla illustration published in 1831 with the two watercoloured paintings signed "R.T.L." in the "Ex Bibl. R.T. Lowe" collection at RBGK, and taking into account the excerpts of Lowe's letters, it is safe to say there is a clear link between them. All details depicted in the published illustration were directly engraved after Lowe's watercolour, since they are exact copies of these details. Moreover, the numbering of figures in the plate matches the corrected numbering of the details in the original watercolour presented in figure 3, from 2 to 12.

The whole plant, however, does not exactly match Lowe's drawing. It may have been lithographed after a different drawing or after a living plant. However, if the plant had been lithographed from another original drawing by Lowe, the author would have been identified, as were the authors of the other plates in his paper. Considering that Lowe told Hooker he had "left with Mr. Hunneman for you a box of plants of Goodyera [...]. I brought drawings of it with me which were intended for you, but [...] I am now having them lithographed", it is safe to assume that Engleman did not have a flowering plant to draw from. Lowe carried from Madeira to England both plants and drawings intended for his friend Hooker, but he only delivered the plants, since the drawings were kept to be lithographed by Engleman. Plausibly, Lowe's drawing may eventually have served as inspiration, being freely transcribed into lithography by the engraver, who took some liberty in his etching. There are several resemblances linking the two images: the positioning of the plant in the plate is similar, with the inflorescence scape "broken" so that the plant fits the page in natural size; the general form of the creeping rhizome and the base of the flowering stem is quite the same, although mirrored; six leaves are represented in both images, with the lower one bending behind the rhizome. Moreover, the slightly wavy stem represented in the published plate, although very elegant, does not correspond to the actual plant, which is perfectly straight, as represented in the original watercolour (see figure 4). The fact that the published illustration is not a precise copy of the watercolour is, undoubtedly, why the author of the original drawing is not identified. Adaptation of the original drawings to fit the requirements of the editor was not uncommon, at the time.

The resulting publication was certainly appreciated by Lowe's fellow naturalists, since it was reprinted twice. Professor Henslow thought it worth sending to his pupil Charles Darwin (1809-1882), who was about to embark aboard HMS Beagle, on his way to the Southern Hemisphere: 


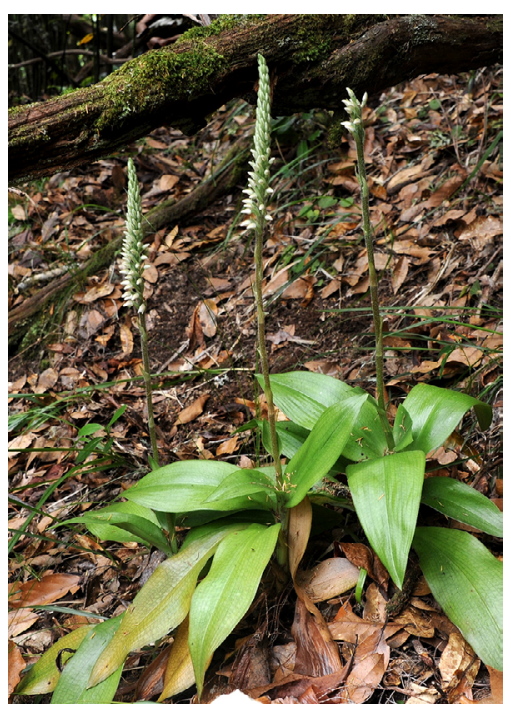

Figure 4. Goodyera macrophylla Lowe in its habitat.

Photo by Miguel Menezes de Sequeira.

As I have received the plates to Lowe's paper, I thought it w[oul]d be a pity not to forward them to you, \& so shall entrust them to L. Jenyns who goes to Town tomorrow to send by some Plymouth Coach-They may be of service in directing your attention whilst collecting land shells (Henslow 1831, November 20).

In the time span 1829-1833, Lowe showed an active interest in improving his drawing technique and talked about publishing plans. In 1832, he wrote to W.J. Hooker:

I have no brush thicker than a knitting needle nor any proper colors for greens. If you would give me a little instruction in coloring you see how useful it would be, and if I could acquire tolerable rapidity I could send you abundance of useful drawings. I find no difficulty at all in sketching; coloring is the business. (Lowe 1832, May 18).

\section{And subsequently:}

Your remarks for my drawings make me just proud -not of the drawings but of your kindness in giving me such encouragement. If you can spare me some time or other any of your own castaways, I shall then perhaps learn how to remedy some of their defects. I have no idea for instance how to give any Shades to a flower of great depth and intensity of coloring except by imparting so much dullness to the whole as to be intolerable in contrast with the vividness of nature. Greatest freedom I suppose may come in time. (Lowe 1832, December 5). 
No sketches of Lowe were found dated later than 1833. This year he became chaplain in Madeira, getting more involved in clerical duties, temporarily laying botany aside. At that time, he became quite enthusiastic about the work of Mary Young and Caroline Norton, accomplished artists who, for some time, illustrated his works. In a letter to W.J. Hooker (Lowe 1833, August 22), he even asks for the price of octavo and quarto plate engraving and colouring, for "a scheme for publishing in $\mathrm{N}^{\text {os }}$ 'Illustrations of the Mada. Fla.'-quite in embryo as yet". However, this project was never carried out, and Lowe's interest in botanical illustration seemed to have vanished in the early 1840s, when he controversially became involved in AngloCatholicism, the so-called 'Oxford Movement', which would take him back to England.

These are the first results of a broader research concerning the work of Richard Thomas Lowe. Illustration was a significant tool in Lowe's exploratory work of Madeira's native flora, at least during the first decade he spent on the island. Drawing may have been part of his process of botanical discovery, and in the development of the observation and analytical skills required for deriving distinguishing characters in specimens of potential new species.

It is clear that, during those early years, Lowe made an effort to illustrate new species and that he made plans to produce an illustrated Flora of the archipelago. Results from this effort can be found in the illustrations marked "Ex Bibl. R.T. Lowe" in the Archives at the RGBK, mostly unpublished. These plans were later abandoned, since Lowe's Manual flora of Madeira-to this day a major reference work for the Botany of Madeira-is not illustrated.

Nevertheless, Lowe's approach to the research of Madeira's native flora was pioneer in its systematic character and because he studied plants in their natural habitat. In the 1820's, when Lowe arrived in Madeira, it was not an unexplored territory and many of its native plants were already known and commonly cultivated in European gardens, thanks to the work of several plant collectors. Therefore, the abundance of new species he found came as a surprise and Lowe may have felt overwhelmed by the dimension of the task in front of him, as he told Henslow (Lowe 1829, May 6): "I have been working without intermission all winter at my Fauna and Flora, but matter grows so on my hands God knows when I shall get through with it. Fresh plants turn up every day and often new ones." Lowe's botanical work in Madeira resulted in more than 200 plant species new to science.

\section{ACKNOWLEDGEMENTS}

The authors would like to thank the staff of the Library, Art \& Archives at the Royal Botanic Gardens, Kew, of the Natural History Museum Archives, London, of the Cambridge University Archives, and of the Bath Royal Literary and Scientific Institution for their assistance. We thank Nuno Senos for comments and suggestions, Jorge Capelo for reviewing the manuscript and João Crisóstomo for graphic enhancement of photographs. We thank the referees for their valuable 
comments and suggestions, that significantly improved the text. This work was funded by FCT PhD scholarship SFRH/BD/117226/2016.

\section{AUTHORS CONTRIBUTION}

Conceptualization: all authors.

Methodology and data gathering: SM.

Data analysis: SM.

Original draft: SM.

Review and edition of the final draft: all authors.

ReCibido: junio de 2019; ACEPTADO: enero de 2020 


\section{REFERENCES}

Bleichmar, D. 2006. Painting as Exploration: Visualizing Nature in Eighteenth-Century Colonial Science. Colonial Latin American Review 15: 81-104.

Brittain, J. 2006. The plant lover's companion. Plants, people and places. Cincinnati, Ohio: Horticulture Books (David and Charles) $192 \mathrm{pp.}$

Brotero, F.A. 1788. Compendio de botanica ou noçoens elementares desta sciencia, segundo os melhores escritores modernos, expostas na lingua portugueza. Tomo primeiro. Paris: Paulo Martin $471 \mathrm{pp}$.

Brotero, F.A. 1816. Phytographia Lusitaniae Selectior, Seu Novarum Rariorum, Et Aliarum Minus Cognitarum Stirpium, Quae In Lusitania Sponte'Veniunt, Ejusdemque Floram Spectant, Descriptiones Iconibus Illustratae. Vol. 1. Lisboa: Typographia regia 236 pp.

Brotero, F.A. 1827. Phytographia Lusitaniae Selectior, Seu Novarum Rariorum, Et Aliarum Minus Cognitarum Stirpium, Quae In Lusitania Sponte'Veniunt, Ejusdemque Floram Spectant, Descriptiones Iconibus Illustratae. Vol. 2. Lisboa: Typographia regia 264 pp.

Burns, M. 2017. Printing and publishing the illustrated botanical book in nineteenth century Great Britain. Cogent Arts Humanit. 4: 1364058.

Castel-Branco, C. 2004. Félix de Avelar Brotero: botaniste portugais (1744-1828). Paris/Lisboa: Fundação Calouste Gulbenkian 329 pp.

Chansigaud, V. 2016. Scientific Illustrators. In: Lightman B. (ed.). A Companion to the History of Science. John Wiley \& Sons pp. 111-125.

Darwin, C. 1877, July 6. [Letter to Arnold Dodel-Port]. In: Burkhardt, F., Secord, J.A., Evans, S., Innes, S., Neary, F., Pearn, A.M., Secord, A. and White, P. (eds.). 2017. The Correspondence of Charles Darwin: Volume 25, 1877. Cambridge: Cambridge University Press 893 pp.

Francisco-Ortega, J., Santos-Guerra, A., Sánchez-Pinto, L., Duarte, M.C., Rouhan, G., Santiago-Valentín, E., Carine, M. and Romeiras, M.M. 2015. Early scientific illustrations of the Macaronesian flora: an introduction to pre-19th century artworks. Vieraea 43: 219-308.

Henslow, J.S. 1831, November 20. [Letter to C. Darwin]. Darwin Correspondence Project, "Letter no. 150”. Available from http://www.darwinproject.ac.uk/DCP-LETT-150.

Jenyns, L. 1862. Memoir of the Rev. John Stevens Henslow, M.A., F.L.S., F.G.S., F.C.P.S. London: John Van Voorst 278 pp.

Lowe, R.T. 1829, November 12. [Letter P.B. Webb]. FCOHC. Documento digitalizado por el Proyecto Humboldt. Available from http://humboldt.fundacionorotava.es.

Lowe, R.T. 1829, May 6. [Letter to Henslow]. MS Add. 8176/112. Cambridge, UK: Cambridge University Archives.

Lowe, R.T. 1830, August 31. [Letter to W.J. Hooker]. Directors' Correspondence 58/169. Kew, UK: Library, Art \& Archives, Royal Botanic Gardens.

Lowe, R.T. 1830, October 26. [Letter to W.J. Hooker]. Directors' Correspondence 58/170. Kew, UK: Library, Art \& Archives, Royal Botanic Gardens.

Lowe, R.T. 1830a, April 23. [Letter to L. Jenyns]. Jenyns Correspondence BRLSI.LET2002. Bath, UK: Bath Royal Literary and Scientific Institution. 
Lowe, R.T. 1830b, April 23. [Letter to Brown]. Correspondence and papers of Robert Brown. Add. MS. 32441, f. 109-110. London, UK: British Library.

Lowe, R.T. 1833, August 22. [Letter to W.J. Hooker]. Directors' Correspondence 58/179. Kew, UK: Library, Art \& Archives, Royal Botanic Gardens.

Lowe, R.T. 1830, August 22. [Letter to Henslow]. MS Add. 8176/68. Cambridge, UK: Cambridge University Archives.

Lowe, R.T. 1831. Primitiæ faunæ et floræ Maderæ et Portus Sancti sive, Species quædam novæ vel hactenus minus rite cognitæ animalium et plantarum in his insulis degentium breviter descriptæ [read Nov. 15, 1830]. Trans. Cambridge Philo. Soc. 4: 1-70.

Mabberley, D. 2009. Brown, Robert (1773-1858), botanist. Oxford Dictionary of National Biography. Available from https://doi.org/10.1093/ref:odnb/3645.

Newell, H.A. 1931. The English church in Madeira: now the church of the holy and undivided trinity: a history. Oxford: University Press 57 pp.

Peile, J. 1913. Biographical register of Christ's College 1505-1905, and of the earlier foundation, Gods House 1448-1505. Vol. II 1666-1905. Cambridge: Cambridge University Press 954 pp.

SECORD, A. 2002. Botany on a plate. Pleasure and the power of pictures in promoting early nineteenth-century scientific knowledge. Isis 93: 28-57.

Sotheby, Wilkinson and Hodge 1875. Catalogue of the libraries of the late Rev. Richard Thomas Lowe, author of Fishes, shells and Flora of Madeira; Plants of the Salvage Islands; \&c. and of other clergymen, deceased. London: Dryden Press 69 pp.

STAFLeU, F.A. and Cowan, R.S. 1981. Taxonomic literature: a selective guide to botanical publications and collections with dates, commentaries and types, $2^{\text {nd }} \mathrm{ed}$. vol $2.991 \mathrm{pp}$.

Stern, W.T. 1966. Botanical Latin. New York: Hafner Publishing Co. 566 pp. 
